\title{
Money and Morals: An Ethical Reflection on the Principle of Profitability
}

\author{
Dr. Modestus Nnamdi Onyeaghalaji \\ Department of Philosophy, Faculty of Arts, University of Lagos, Akoka Yaba
}

\begin{abstract}
The paper focuses on the philosophical presuppositions of the principle of Profitability, which is a driving value for most human interactions in the public sphere. While the value of profitability drives us to success it has the potential to motivate inhuman actions that undermine human dignity, rationality and social progress. In most African societies, such as Nigeria, the later effect is dominant. The paper employs the idea of Ayn Rand to attempt an understanding of the presuppositions behind this principle of profitability in human endeavor. Rand analyses the idea of rational self-interest and altruism as explanatory principles. She rejects altruism and argues for rational self-interest as the ideal principle that motivates us towards progress and altruism as motivating the opposite. The paper interrogates Rand's position in the light of ideas of J.S. Mills and Kant. It argues that Rand's idea of rational self-interest entails the assumptions of altruism. Where it does not, it promotes extreme-egoism and rugged individualism that undermines social progress.
\end{abstract}

Key words: Profitability, self-interest, morality, altruism, Ayn Rand, egotruism

\section{Introduction}

Value plays vital roles in determining the course of human action. It is the driving force that motivates human conducts and social interactions towards desired goals. Some values are intangible, such as moral values and some are tangible or material, in economic sense, of having some worth or cash value - money. People are usually driven by material values in their social interaction. In business transaction, the material or money-drive has led to exploitations of people and things. Consequently, there is tension between money and morals or profit motive and ethics. Both have symbiotic relationship. Yet profit motive is fundamental to business. It is, therefore, necessary to inquire on what constitutes the morality of profitability.

There are three broad contending positions between the two phenomena. The first is a belief that in any human transaction, including business activities, our objective or moral duty should be to maximize moral wellbeing or communal interest. Robert Heilbroner, as quoted by Lyoyd Eby, for instance, hinted that the quest for profit is a recent phenomenon in history; America-Pilgrim Fathers would have considered profit motive to be from the devil and therefore sinful ${ }^{1}$. The second group of beliefs maintains that the basic characteristics and objective of business is to make profit and not any moral consideration. John Locke, Ludwig von Mieses, Fredric A. Haryek and Adam Smith among others insist that profit motive is morally right business objective and the basis for social good. The third group maintains that there is no intractable conflict between morality and business activity or "between ethical practices and acceptable profit". The first could be a necessary precondition of the latter ${ }^{2}$ or cooperate social responsibility could fill any gap between them.

The paper employs the ethical views of Ayn Rand to interrogate these positions especially from the perspective of the second group. The aim is to underscore, philosophically, moral presuppositions behind the principle of profitability. Ayn Rand, a rational egoist, provides an idea of rational self interest as a moral code for profitability, and as a theoretical basis for justifying profit motive. The paper interrogates the rational selfinterest within an ethical context, altruism, as adumbrated in the thoughts of John Stuart Mill and Immanuel Kant. It maintains that while profitability is fundamental in motivating human conduct, it would have ethical tenor and promote general wellbeing if it is situated within the context of a more humane normative value, referred to here as egotruism - an integration of the basic values of moderate egoism and altruism.

\section{The Principle of Profitability and the Implications for Morality}

The basic assumption here is that profit motive has potentials (1) to motive human actions towards success and social good, and (2) to motivate inhuman actions that undermine human dignity and thwart the course of 
social unity and progress. The first motivation arises in a situation where moral agents operate within the context of social morality and propitious social condition. The second motivation drives in situations where the agents and social-political conditions are deficient in moral values

These basic assumptions demand explication. Human beings are in continuous interactions and relationship with each other. One of the medium of these interactions is business. Business activity is concerned with provision of goods and services and receiving of rewards accruing from the goods and services provided. Lloyd Eby defines it as an activity that is concerned with creating, manufacturing, supplying or distributing commodities, information or services for payment by recipient of these commodities, information and services ${ }^{3}$. The central aim of business is profit making.

Richard P. Mullin Jr describes the idea and place of profit making in traditional model of market using John Locke's views like thus: natural resources belong to everyone, but they do not constitute wealth until someone provides value by his labour. Since labour produces wealth, the wealth is the property of the person who has produced it. He can use his surplus to trade for other goods and to invest ${ }^{4}$. What is invested in the business is the input. The business person expects the total outcome to be greater than the input. The input and the output are usually assessed in monetary terms. The "money received for the output that exceeds the cost of all the inputs into the business is known as the profit" ". It indicates that profit requires some rational economic order. In the order, effort, hard work, and efficiency are required to produce more and consume less to get greater-profit. The more profit the agents get the more motivation they are to engage their hard work and rationality for more.

\subsection{The Motivational Principle of Profitability}

Profit ethic is the motivating principle for business transactions and market economy. The reasons are obvious. People engage in transactions for what they stand to gain. It would be considered inappropriate to spend ample time, labour and resources only to gain nothing. In Business Ethics and Values, $\mathrm{H}$. C. Mruthyuanjaya attempted to provide reasons for the motivational principle of profitability. According to him, business people have to make profit because establishments have to survive in a highly competitive market; investors in business expects returns for comfort and social security; the business establishments need to pay good compensation package to those who run the organization; employers deserve their wages; the establishment need money to repair its damages and must explain demands. He concludes that making profit is not a $\sin ^{6}$. However, it is not everyone that has always thought that it was moral and legitimate to strive for profit or to see it as a driving force for human activities, business and otherwise. Robert Heibroner, an economist has asserted that profit motive is a relatively recent phenomenon in history. He claims that American-pilgrim fathers, for example, would have posited that profit motive, the idea that profit is to be strived for is from the devil ${ }^{7}$. In the history of philosophy, the cynics, such as Diogene would consider the surplus and material profit as irrelevant and inhibitor of happiness ${ }^{8}$. In another sense, but following the same principle, the proletarian world view developed to oppose profit motive. Notwithstanding, profit is known today as the goal of business. It is the motivating force for industries and companies ${ }^{9}$.

It is necessary for both capitalists and non-capitalists. Business is conducted for many reasons, but profit interest is central to it. Company owners, managers, business people are motivates by profit and for more and more profits.

The economic principle of profitability therefore is that profit making is right as well as a duty. The principle entails that the idea of profit motivates efficiency and industriousness and cultivates disciplines and cautiousness, for healthy economy and morality among individuals. This is precisely because, through efficiency and discipline, hardwork is put in place to produce more that can be consumed. And through discipline, extravagancy and calumny is curtailed, and more profit is made. The justification for the principle is production of wealth. Can this justification be a moral one such that it qualifies the description, profit ethics? Richard Mullin identifies the difficulties that confront the idea of profit ethics ${ }^{10}$. He argues that that profitability may not guarantee sustainable wealth and may create ethical problems, such as exploitation of people's ignorance, destruction of the environment, using up of energy resources, and health risks from industrial products. However, Ran provides ethical code to justify the principle of profitability. 


\section{Ayn Rand's Rational Self Interest and the Ethics of profit Motive}

Ayn Rand provides 'morality of rational self interest' as a foundation for understanding the principle of profitability for human progress. A clarification of her conception of 'morality' and 'rational self-interest' would be necessary here. Morality, according to Rand, is “a code of values to guide man's choices and actions. It is the code by means of which one judges what is right, good and evil" ". The idea of morality as a guide to human conduct is generally agreed. But Rand provides a distinctive reason why see need guideline and for what purpose. Unlike most philosophers, she does not see morality as primarily a guide to treating or caring for others. She, rather, sees morality as a guide to life, in any context, whether social or individual. The purpose is to live, to survive and flourish and to achieve our goals, such as successful business, productive carrier. In essence, man needs morality for selfish reasons, to live and flourish.

Consequently, she rejects altruism and its variants that see morality as a guide to the service of others or a guide to achieving equality among people in the society. According to her, altruism means self-sacrifice, selfimmolation, self-abnegation, self-denial, and self-destruction. It is living for others. Rand maintains that the basic and irreducible principle of altruism is that "man has no right to exist for its own sake" that service to others is the only justification of his existence, and "that self-sacrifice is his highest moral duty", virtue and value. ${ }^{12}$ She opines that it is altruism that makes people to deny "that they are seeking their own happiness" and "business men to be afraid to say they are making profits". It does not recognize the value of self, the value of one's life and one's existence. One's existence does not depend on the need of others. One should not be a sacrificial animal to others. There is no earthly reason for that.

In her thought, it is egoism that recognizes the primacy of live and self interest. One's concern should, therefore, be one's value whether they are career, family, friendship or freedom. Rand's morality is concerned with self-interest. It is called moral egoism - which places what is good for the self over and above others. Life is the central value. Every other thing is valuable in relation to human life. There is an objective requirement for sustenance, survival and flourishing of human life. She identified the basic requirements as reason and freedom. Freedom is an existential characteristic which Rand sees as absence of any constriction or compulsion (political freedom). Man must be able to make choices and chose his action and must not be coercion. Reason is a psychological element, which conceives as defining characteristics of man and his valuable means of survival.

Reason is the faculty which perceives, identifies and integrates the material provided by man's senses. Reason integrates man's perceptions by means of forming abstractions or conceptions, thus, raising man's knowledge from the perceptual level, which he shares with animals to the conceptual level which he alone can reach. The method which reason employs in this process is logic-and logic is the art of non-contradictory identification. ${ }^{13}$

In Atlas shrugged, she maintains that man is a being of volitional consciousness and to think is an act of choice. Reason does not work automatically. You are free to think or to evade the effort. Reason is man's means of survival. Man must choose a code of values to guide his actions. It presupposes a standard, a purpose and (a necessity of action in the face of) alternatives. No values are possible when there are no alternatives. There is only one alternative that pertains only to living organisms. That is, existence or no existence. It is either life or death. Life is a process of self sustaining, self - generating. If an organism fails to sustain its life, it dies. Man does not possess an instinct of self preservation to sustain his life as people think, precisely because an instinct is an automatic form of knowledge. He must rather obtain his knowledge and chose his actions by the process of thinking which nature would not force on him. He can preserve his life or destroy it. He has alternative between survival and suicide. For a person to live and achieve his values, he must utilize his distinctive form of consciousness, his power to conceptualize so as to indentify his needs, create means of satisfying them to anticipate various eventualities, to plan and take appropriate actions. He must try to discover how to survive - to invest, cook, and build shelter. He must be free to act on his thinking. He is a man by choice; he has to hold his life as a value by choice, sustain it by choice, discover his values and practice virtues by choice. A code of value that is accepted by choice is morality. Therefore, she maintains that there is a "morality of reason, a morality proper to man, and man's life is the standard of value". From this, Rand deduced her moral maxim by stating that "all that is proper to the life of a rational being is good; all that which destroys it is the evil" 14 . While man's life is the standard of morality, one's own life is its purpose. It implies that a rational egoist determines if an action is good or bad by examining its impact on one's ability to survive in a long time. In order to live on this 
earth, as an existential goal, one must chose one's actions and values by the standard of that which is proper to man, for the purpose of preserving, fulfilling and enjoying the irreplaceable value which is one's life. Rand's morality is a morality based on man's right to exist.

The idea of freedom and reason which is behind the rational morality of self interest is what "created in $19^{\text {th }}$ century, a new economic system, a system of free trade on a free market, called capitalism". Rand employs this to justify capitalism, because it is based on principle of freedom and survival. It created wealth in Europe, America, and she said it would have done more if not for the problem of government restriction. She argues that the moral justification of capitalism is man's right to exist for his own sake and not for the sake of others. He is an end in himself and not a means to end of others. She writes,

The moral justification of capitalism is man's right to exist for his own sake, neither sacrificing himself to others nor sacrificing others to himself; it is the recognition that man - every man - is an end in himself, not a means to the ends of others, not a sacrificial animal serving anyone's need ${ }^{15}$

She thinks that an attempt to justify capitalism on the ground of public good or general welfare is non deserving because these are its secondary consequences. It can rather be justified on moral ground. From the analysis, it becomes obvious that Rand justifies the idea of profit motive on the moral ground that it correlates the notion of rational self interest. The objective is to sustain one's life goal, survival and sustenance.

\section{Rational Self-Interest and the Moral Code of Altruism: Kant, and Mills}

Does the morality of rational self-interest, logically ensure social good, which is behind the objective of altruism, as intended by its proponents, such as Emmanuel Kant and J. S. Mills. The Idea of rational morality of self-interest in Rand's thinking, provides a moral justification for the principle of profitability. It justifies profit motive on the ground that it is a rational attempt to seek for means of survival, life sustenance and flourishing in the society. Rational morality of self interest, accordingly justifies property accumulation, inventions, productivity, in so far as one does not sacrifice his life for others and others do not sacrifice their lives for one. In what follows, we need to consider how this squares with the idea of living in the society with others. This consideration must be done by examining Rand on two levels: (1) the adequacy of her rejection of altruism (and its variants utilitarianism and egalitarianism) on the ground of its meaning and promotion of self-sacrifice and (2) her conception of rational self-interest as a plausible moral code for the principle of profitability.

\subsection{Altruism and the principle of Profitability}

In Rand's view, the moral code of altruism is incompatible with the principle of profitability; this precisely because altruism does not promote self interest but undermines it. Altruism takes actions motivated by profit motive as immoral because that would be antithetical to selflessness that altruism promotes. Accordingly, it is anti-capitalism and against any attempt at realization of individual ultimate goal of self survival.

In his work, "Egoism versus Rights', Robert Bass, rejects Rand's position that altruism is inconsistent with respect for individual rights. Bass sees Rand's interpretation of Altruism as a distortion of the concept. ${ }^{16}$ In response to Bass' criticism, Robert Campbell, argues in "Altruism in Auguste Comte and Ayn Rand", that Rand might have overstated the idea of altruism in Kant or Max, Mill or spencer, Dewey or Rawls due to the manner she horridly ran over their views, however, her characterization of altruism is Comtean. She only adopted Comte's description of Altruism ${ }^{17}$. Comte is said to be the inventor of the word altruism and he defined it as "living for others" (vivra pour autrui) and insists that an "individual must subordinate himself to an Existence outside himself in order to find in it the source of his stability". ${ }^{18}$ Therefore, Campbell argues that when Rand describes Altruism as placing other's interest above one's interest, she is simply replicating the intent and belief of the progenitor. Campbell went further to argue that after Comte some form of altruism have been theorized, giving rise to some weaker theories of altruism and some generalized theories of altruism. He concludes that "Bass should be complaining about, a weaker or more wavering conception of altruism instead of criticizing Rand who was merely represents the intensions of the founder ${ }^{19}$. The analysis of Campbell reveals that from the time of the founder to the present, the idea of altruism has acquired varied interpretation. That means there are various interpretations even by those who are utterly sympathetic to altruism.

John Stuart Mill is one of the major proponents of a variant of altruism referred to as utilitarianism. He was one of the "financial supporters of Comte's efforts", but "found his System of Positive Polity bizarre and grossly 
illiberal." ${ }^{20}$ After the demise of Comte, Mill criticized openly Comte's idea of altruism. Mill avers that Comte moved from the belief that "the good of human race is the ultimate standard of right and wrong" and from the belief that "moral discipline consists in cultivating" certain virtues against vices that are "injurious to the general good"; to the conclusion that "we should starve desires which point to our personal satisfaction" or gratification. Mill states that "to live for others" is the golden rule of morality for Comte's religion, which simply reduces the "objective of moral disciple to altruism ${ }^{21}$. And by so doing, loving others as you love yourself was meaningless to him

Nevertheless, Mill does not reject altruism outright because he is altruistic house what he challenges here is the extreme position of Comte's altruism. He accepts altruism as basic to morality and good one at that. However, he thinks that the concept should be redefined or left as it is without effort to define. Mill's utilitarianism is a systemic expression of his utilitarianism theory. Utilitarianism has been described to advocate "sacrificing individual interest for the public good". ${ }^{22}$. This may also not describe in the most accurate way, Mill's utilitarianism, since it also takes utilitarianism to the extreme of altruism; but it may describe better some utilitarian tempers, such as that of Bentham. For instance, Mill agrees on the utilitarian greed of "moral utility" or the "greatest happiness principle", which holds that we should always act in a manner that will maximize overall happiness. Accordingly, Mill states "actions are right in proportion as they tend to promote happiness, wrong as they tend to produce the reverse of happiness" ${ }^{23}$. Notwithstanding, Mill seem to recognize the place of individual happiness in the network of utilitarian doctrine. He stated clearly that most of the good actions are intended for the individual good from which the good of the world is made up.

The great majority of good actions are intended not for the benefit of the world, but for that of individuals, of which the good of the world is made up, and the thoughts of the most virtuous man need not on these occasions travel beyond the particular persons concerned, except so far as is necessary to assure himself that in benefiting them he is not violating the rights, that is, the legitimate and authorized expectations, of anyone else $\mathrm{e}^{24}$.

It implies that while utilitarianism seeks for the greatest good of the society, not all utilitarian views does advocate for the sacrifice of individual happiness or profit. Why there could be extreme position of utilitarian believes, it does not always entail self abnegation. Secondly, objective of utilitarianism may not be to alienate the individual actor but to create a standard for maintaining the condition for social good in which the happiness of the individuals can be realized.

Another altruistic theorist is Immanuel Kant. Kant's ethics of duty was heavily criticized by Rand for his mystification of the code of human moral conduct and subverting course of human rationality in his altruistic doctrine. Obviously, Kant's moral philosophy is altruistic. It is set for the good of mankind. Kant considers morally good conduct as the act which is performed for the "sake of duty" 25 . To act for the sake of duty is to act, not because one hopes to gain anything from the actions or because one feels like doing it. It is also not because of one's natural inclination to do such things like eating food. It is purely out of reference or obedience to moral law. According to Kant, it is only such acts that are performed for the sake of duct that have moral value. If we perform an act simply because of the material benefits or gains or profits, such acts do not have moral value. Kant's idea of actions for the sake of duty is inconsistent with the principle of profitability. But there are other aspects that can accommodate the principle of profitability. One is the principle of universalization as a criterion for knowing right or wrong action. He suggests that if you want to know whether the action you intend to perform is morally right or wrong, look at the maxim of the action, the underlying principle. Would you consider that it becomes a law for everyone to act the same in similar circumstance? For instance, someone comes to buy goods from you unknown to him but know to you that it is expired. If you intend to sale the goods without disclosing the condition of the goods, you ask yourself, would you prefer it becomes a universal law for anyone to sale a good known that it is not in good condition to an unsuspecting customer? If your answer is positive then it is a sign that it is a right act. Secondly, Kant suggests in one of its maxims that no man should be used simply as means to one's ends. it is an offence against moral law to use human dignity as a means to an end ${ }^{26}$.

What we intend to point out here is that even though Kant's altruism has some extremity, it also recognizes the place of individual dignity in the network of ethical theorizing. Accordingly, it does not totality exclude the idea of profitability as regards preservation and respect of life. It accommodates profitability in as much as it is earned without undermining human ends and dignity in oneself or the other. 


\subsection{Rational Self Interest and its Altruistic Elements}

Rand's idea of egoism in one aspect succumbs to extreme individualism and in another aspect it gives room to social individualism. In promoting extreme individualism, Rand argues for political freedom, freedom from compulsion, absence of any government interference and control, and free market moral economy. She refers to it as "full, unregulated, totally laissez-faire capitalism"27. This is one of the reasons she sees rational self-interest, the moral cod of egoism to be diametrically opposed to altruism. It is obvious from history that human greed can be stretched when there is no element of regulation and that is why ethical codes are needed to regulate human needs.

In another aspect Rand's rational self interest seem to be relaxed to accommodate others' self interest. According to Tara Smyth, Rand's understanding of egoism as the concern with one's self-interest does not suggest that an egoist should live a life of a hermit with no concern for or interest in other people. Rand's egoism merely holds oneself as the primary, but not only - value, and advocates the achievement of one's values, whether they are a career, a family, friendship or freedom". ${ }^{28}$ Rand's herself argues that everyman is an end in himself and no one should sacrifice himself for others nor sacrificing others to himself. In that case, human action is considered right if it promotes the right of existence without compromise that of others. In another way, this could be referred to as 'enlightened egoism' "which considers others in determining the right action"29 or "which takes a long-range perspective and allows for the well-being of others, although one's own self-interest remains paramount" ${ }^{, 3}$. It implies that there is an aspect of egoism that accommodates altruistic elements without leading to self-sacrifice, abnegation.

\section{Rational Self-Interest as the Principle of Profitability and its Implications for Human Well-Being}

The preceding discussions indicate that self interest is the motive behind most human transactions. It is central to egoism and altruism but in some distinct ways. In egoism, self-interest is primal and has different existential referents that manifest in two broad conceptions of egoism - extreme egoism and moderate egoism. Extreme egoism takes a parochial and crude perspective and allows only one's own self-interest irrespective of its effect on the others. Such egoism is predatory and robs off on both the individual and the society. Moderate egoism on the other had takes a wider and long-rage perspective and accommodates the well-being of others but takes own self-interest as the central. This is what has been referred to as enlightened self interest. It also describes Rand's rational self-interest when it is not being exclusive.

In altruism, self-interest also manifests in two senses - extreme and moderate altruism. Extreme altruism entails self-sacrifice described in Comtean parlance as "live for others". This is the sense of altruism that Rand critically challenged and rejected. Campbell describes it as "wavering altruism" 31 . Extreme altruism is actually idealistic and difficult to realize. Herbert Spencer calls it pure or perfect altruism and rejected it as being perverse and suicidal ${ }^{32}$. It is incompatible with profit motive. Moderate altruism entails a rational and sympathetic consideration of others interest; it is a recognition of the fact that the other is a person of value and should be considered in decisions and actions that may have affect on him.

These distinctions between the extreme egoism and moderate egoism on one hand and between pure altruism and moderate altruism are to show that egoism and altruism are two ends of a continuum. Their middle point is their moderate descriptions. Moderate egoism and moderate altruism are same - they constitute what can be referred to as egotruism. Egotruism is the integration of the values of egoism and altruism in their moderate positions. Consider the continuum from point A (extreme egoism) through B (moderate egoism) and C (moderate altruism) to D (Extreme altruism), and E egotruism 


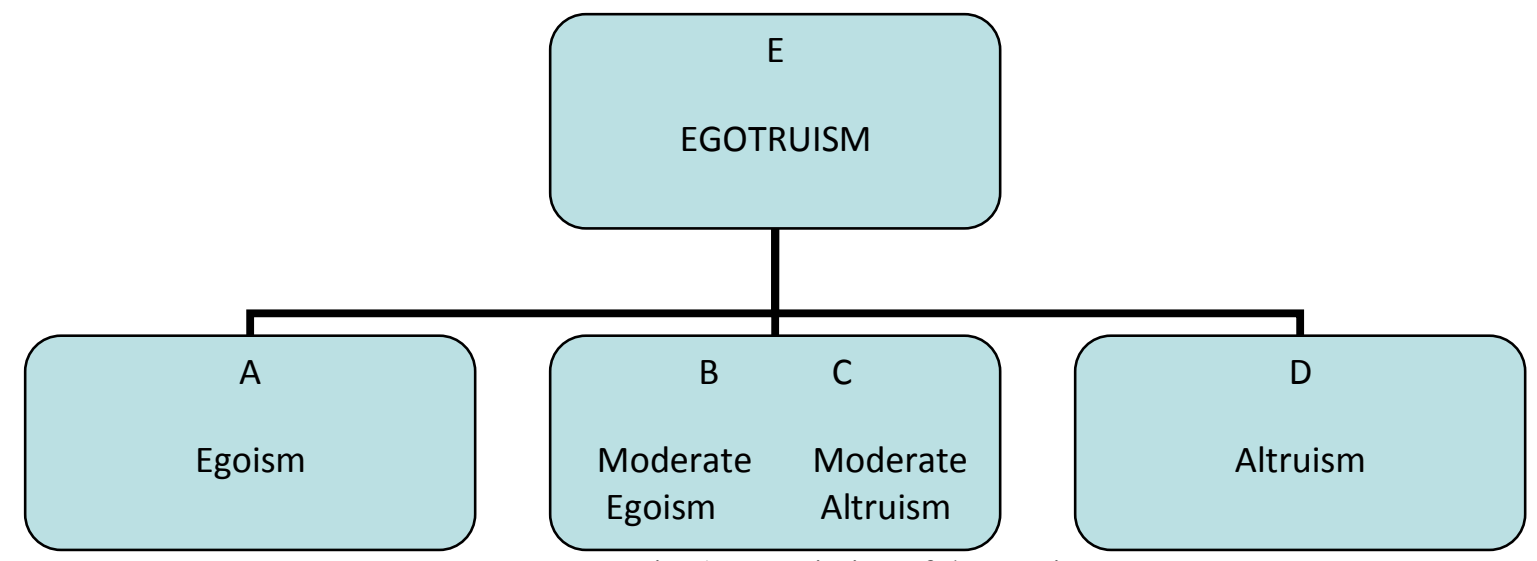

Fig. 1: Description of the continuum

The point is that rational self-interest or enlightened egoism, describes more, what is intended by egotruism when it is considered as a reflective consideration of one's interest without fundamental exclusion or conscious subjugation of the interest of others. It is an intelligent consideration of the self that does not live in isolation but in community with the other selves. Tara smith's analysis of virtuous of egoism gives expression to this. One of the common virtuous is honesty. Honesty, according to Rand, is being true to reality, refusal to fake things, such as "deliberately omitting pertinent information about a subject, covering something" 33 . Faking things or manipulating reality amounts to dishonesty which is self-deception and deception of others.

In that case, if rational self-interest excludes the other selves in practical considerations, it relapses to unwavering selfishness that is anti-social. If it excludes own self and takes the other selves as paramount, it degenerates to self-sacrifice and self abnegation. In Nigeria, for instance, there are cases of self interest motivated businesses that excludes the consideration of the other. The formal NAFDAC chairman, Prof. Dora Akunyili, disclosed instances of manufacturing and selling of fake drugs among the business people.

Prof Dora Akunyili was a director-general of the National Agency for Foods Drugs Administration Control (NAFDAC). For instance, in June 2006, she closed Sabon Gari drug market in Kano and well known Onitsha Drug market for manufacturing and selling of fake and substandard drugs ${ }^{34}$. In 2007, she seized 82 truckloads of fake, banned and expired drugs and closed five fake drug warehouses at the same Onitsha drug market. Onitsha Market is a big market in the Eastern part of Nigeria. According to World Health Organization survey, it has $30 \%$ fake drug prevalence as against $10 \%$ in other parts of the country ${ }^{35}$. The effect of fake drugs on the health of the citizens cannot be quantified. In these instances, such acts are motivated by profitability in which the moral code is extreme self-interest, crude, un-enlightened and predatory egoism. This is a case of rationalization of self interest than rational self-interest. It is dishonesty because it manipulates reality for deception of oneself and the other.

\section{Conclusion}

The paper set out to identify the morality of the principle of profitability in human transactions, business and others. It examines Rand's idea of rational morality of self interest. It discovers that morality of self-interest which Rand defends has two senses - extreme and moderate. The extreme sense is diametrically opposed to extreme altruism that Rand critically rejected. The code of the extreme morality of self-interest creates condition for unhealthy rivalry and absolute individualism. The moderate sense, which is actually inherent in Rand's rational self-interest, has altruistic strands; it is not different from moderate altruism. Both recognize the importance of the individual interest and that of others in social interactions and business transactions. Thus, the argument is that rational self-interest is the moral code of profitability; when it entails the assumptions of altruism in its moderate sense - egotristic, it creates ambiance for social growth. Where it does not, it promotes rugged individualism that undermines social progress. Meanwhile, there is a need to explore further, perhaps in another context, the basic principles of egotruistic morality.

${ }^{1}$ L. Eby, Business and Professional Ethics, USA: University of Maryland University College, 1995, unit 3, p.3 
${ }^{2}$ David Hegel, "Ethics and Profit don't always go Hand in Hand", in Business Ethics 92/93. D. E. Richardson Editor, Fourth Edition. Guilford Connecticut: The Dushkin Publishing Group, Inc. 1992, Art 8, Page 41

${ }^{3}$ L. Eby, Business and Professional Ethics, USA: University of Maryland University College, 1995, unit 3, p.1

${ }^{4}$ R. P. Mullin Jr., "profit Making: the Creation or the Destruction of Wealth?", in Business Ethics in Canada. Debora C. Poff \& Wilfrid J.Waluchow, Scarborough Ontario: Prentice-Hall, Canada, Ch. 42, p.415.

${ }_{6}^{5}$ L. Eby, Business and Professional Ethics, Unit 3, p.2

${ }^{6}$ H. C. Mruthyunjaya, Business Ethics and Values system, Delhi: PHI Learning Private Limited, 2013: p.145-155

${ }^{7}$ R. Heilbroner (1985) in Llyod Eby, Business and Professional Ethics, USA: University of Maryland University College, 1995, p.3

${ }^{8}$ J. Gaader, Sophie's World, Ibadan: spectrum books Limited, p. 102

${ }^{9}$ D. P. C. Poff and W. J. Waluchow, Business Ethics in Canada, Scarborough Ontario: Prentice-Hall, Canada, p.46

${ }^{10}$ R. Mullin, "Profit Making: the Creation or the Destruction of Wealth", in Business Ethics in Canada, D. C. Poff and W. J. Waluchow, Scarborough, Ontario: Prentice Hall Inc: p.45.

${ }^{11}$ A. Rand, Philosophy Who Needs it, USA: Penguin Books, 1982. Ch.7. P.61. A. Rand, “The Objectivist ethics". In The Virtue of Selfishness: A New Concept of Egoism. New York: New American Library, 1964. P.22-23.

${ }^{12}$ Ibid, p.61

${ }^{13}$ A. Rand, A. Rand, Philosophy Who Needs it, USA: Penguin Books, 1982.p.62

${ }^{14}$ Ibid, p. 75.

${ }^{15}$ A. Rand, Philosophy Who Needs it, USA: Penguin Books, 1982.p 67

${ }^{16}$ R. Bass, Egoism versus rights. The Journal of Ayn Rand Studies 7, 2006, n o.2 (Spring): pp32 9-49.

${ }^{17}$ R. L. Campbell, "Altruism in August Comte and Ayn Rand", Journal of Ayn Rand Studies, Vol. !. No.2, (Spring 2006) pp.357-369

${ }^{18}$ See C. Auguste, System of Positive Polity, Volume 1: Containing the General View of Positivism \& Introductory Principle. Translated by John Henry Bridges. New York: Burt Franklin. p.565. (Original work published in 1954). See also Vol. 4: Continuing the Theory of the Future of Man. Translated by Richard Congreve and Henry Dix Hutton. New York: Burt Franklin. (Original work published 1854).

${ }^{19}$ R. L. Campbell, "Altruism in August Comte and Ayn Rand", Journal of Ayn Rand Studies, Vol. !. No.2, (Spring 2006) pp.367

${ }^{20}$ Ibid, p.363

${ }^{21}$ J. S. Mill, Auguste Comte and Positivism, London: N. Trubuer and Co. 1965, pp.138139.

22 J. Woiceshyn, "Ayn Rand's Normative Ethics: The virtuous Egoist, by Tara Smith" (Cambridge: Cambridge University Press, 2006, 318 pages), book review. In Business Ethics quarterly, vol.18, Issue, 1, pp117-135

${ }^{23} \mathrm{~J}$. S. Mill, Utilitarianism, $2^{\text {nd }}$ edition, edited with an introduction by George Sher. Indianapolis/Cambridge: Hackett Publishing Company, Inc., Ch. II, p. 7.

${ }^{24} \mathrm{Ibid}$. p. 19

${ }^{25}$ Immanuel Kant, Groundwork of the Metaphysic of Morals, p. 5

${ }^{26}$ Immanuel Kant, Critique of Practical Reason, part 1, book1, Theorem IV

${ }^{27}$ A. Rand, "Faith and Force: The destroyers of the Modern World, (1960)". In Philosophy Who Needs it, USA: Penguin Books, 1982. Ch.7. P.66.

${ }^{28}$ Tara Smith, Ayn Rand's Normative Ethics: The virtuous Egoist, Cambridge: Cambridge University Press, 2006, J. Woiceshyn, p.120

${ }^{29}$ I. Maitland, "The Human face of Self-Interest", Journal of Business Ethics, 2002, vol. 37pp

${ }^{30}$ O. c. J. Ferrell, and L Ferrell, Business Ethics: Ethical Decision Making and Cases. Boston: Houghton Miffflin, 2005, p.27

${ }^{31}$ R. L. Campbell, "Altruism in August Comte and Ayn Rand", Journal of Ayn Rand Studies, Vol. !. No.2, (Spring 2006) pp.364

${ }^{32}$ H. Spencer, 1978, The Principle of Ethics, Vol. 1, Indianapolis: Liberty Classics. (original works published 1879 \& 1892), pp259-262

${ }^{33}$ T. Smith, Ayn Rand's Normative Ethics: The virtuous Egoist, Cambridge: Cambridge University Press, 2006, p.76

${ }^{34}$ The Sun, Saturday.07.June41,

${ }^{35}$ Tribune, Nigerian 2007 